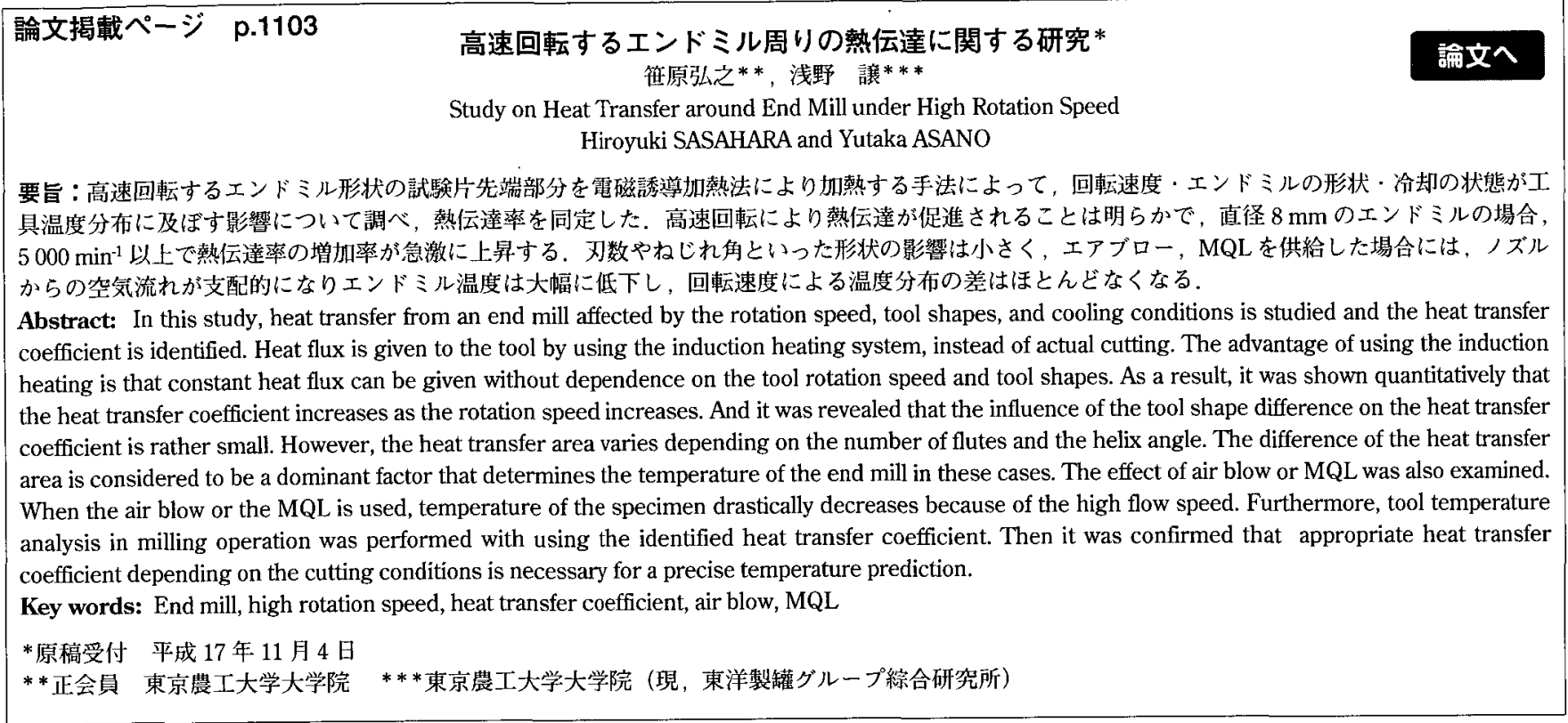

\title{
論文掲載ページ p.1108
}

\section{高硬度軸受鋼の回転曲げ S-N 試験の毒命分布と信頼性 * 一新 P-S-N 曲線の適用-}

清水茂夹 $* *$, 当舎勝次 $* *$, 上田大介***, 下田博一**

Life Distribution and Reliability for Rotating Bending S-N Test on Highly Hardened Bearing Steel

- Application to New P-S-N Curves -

Shigeo SHIMIZU, Katsuji TOSHA, Daisuke UEDA and Hirokazu SHIMODA

要旨：HRC58～62 に熱処理された軸受鋼 6 ロット，総数 179 本の回転曲げS-N 試験を実施し，破断面の観測結果から表面下の非金属介在物が破損 の起点になること，疲れ限度は現れないこと，およびワイブル分布と対数正規分布ベースの寿命理論を適用して新 P-S-N 曲線を提案し，実験結果と 比較，検討を加えて報告している。

Abstract: A study on the fatigue behavior of bearing steel by using rotating bending fatigue test rigs is carried out for bearing steel (JIS SUJ2) heat-treated to HRC58-62. P-S-N (Probabilistic Stress Life) curves and fatigue life distributions, such as Weibull and log-normal, are used for discussion. As a result, the best fit for a life distribution of six lots with each sample size of around thirty specimens, at the stress levels from 0.94 to $1.27 \mathrm{GPa}$, is obtained by 3-parameter Weibull distribution, followed by the log-normal distribution as second, and 2-parameter Weibull distribution as the third. From the observation of broken section in test piece the initiation point of fatigue failures are almost started from subsurface non-metallic inclusions, $\mathrm{TiN}^{\mathrm{N}} \mathrm{CaO}_{-} \mathrm{Al}_{2} \mathrm{O}_{3}$ and $\mathrm{CaO}-\mathrm{MgO}_{-} \mathrm{Al}_{2} \mathrm{O}_{3}$. The fatigue limit for the bearing steel could not be observed from the experimental result. It is also made clear that the statistical distribution and P-S-N curve model must be described from the same formula, and a rating stress such as bearing rating load is successfully introduced to the 3-parameter Weibull and log-normal distribution.

Key words: P-SN curve, rotating bending fatigue, non-metallic inclusions, fatigue limit, log-normal distribution Weibull distribution, rating stress, linear bearing

* 原稿受付 平成 17 年 11 月 8 日

**正会員 明治大学理工学部 $* * *$ 学生会員 明治大学大学院

論文揭載ページ p.1113

\section{濡れ性パターンを用いた微粒子の自己整列（第 1 報）* 一手法の提案と整列条件の検討一 諸鿓信行**，小木曽淳- $* * *$, 金子 新** \\ Self-Assembly of Fine Particles using Patterned Wettability}

- Proposal of Assembling Method and Consideration of Conditions for Assembly -

Nobuyuki MORONUKI, Jun-ichi KOGISO and Arata KANEKO

要旨：所望の領域に微粒子を整列させる方法を提案している.PTFE あるいは OTS 疎水材, $\mathrm{SiO}_{2}$ を親水材とした縞状の濡れ性パターンを作成し， ポリスチレン微粒子（粒径 $400 \mathrm{~nm}, 1 \mu \mathrm{m}$ ）を含む䜿濁液からの引上げ実験（移流集積法）を行うことで, 最小幅 $4 \mu \mathrm{m} の$ 親水部への整列を行った. 各部の接触角の影響や縞パターンの幅やピッチが整列結果に及ぼす影響を調ベ，条件選択指針を示した。

Abstract: This paper proposes a technique to assemble fine particles combining the continuous-convective-method and patterned wettability. A substrate patterned with hydrophilic or hydrophobic region is drawn-up from suspension that contains particles at specific angle. At the boundary of air/suspension, the particles arrange themselves selectively on hydrophilic region as the evaporation of water. Firstly, we discuss the method of wettability patterning. Line-and-space patterns that consist of $\mathrm{PTFE} / \mathrm{SiO}_{2}$ and $\mathrm{OTS} / \mathrm{SiO}_{2}$ were prepared. Then, the relationship between the contact angle of each region and trapping force of suspension was discussed. Secondary, design guideline is discussed where the condition to full-up the particles only in hydrophilic region is focused. It was found that the width and spacing of hydrophilic region should be designed to keep sufficient supply of particles.

Key words: patterned wettability, contact angle, self-assembly, fine particles

*原稿受付 平成 17 年 11 月 29 日

**正会員 首都大学東京 $* * *$ オリンパス（株）（元，東京都立大学大学院） 
論文掲載ページ $\mathbf{p . 1 1 1 8}$

\author{
CWレーザ背面照射法（CW-LBI）によるガラスの内部変質（第 1 報）* \\ 一変質部の形成条件一 \\ 吉网将人**, 谷 召輝 $* * *$, 比田井洋史 ${ }^{\dagger}$, 戸倉 和 ${ }^{\dagger}$
}

Laser Induced Modification in Glasses by CW Laser Backside Irradiation (CW-LBI)

- Conditions for Inducing Modification by CW-LBI -

Masato YOSHIOKA, Gu Zhaohui, Hirofumi HIDAI and Hitoshi TOKURA

要旨：ガラス板の一方の面に金属䈃を置き，反対の面側からガラスに透明なレーザ光を照射することによって，ガラス内部に屈折率の变化した円柱状 の変質部を形成させることができた．この変質部は 180 ～ $220 \mathrm{~mm} / \mathrm{s}$ 程度の速さでレーザ照射方向に成長し，その直径は照射条件によらずほぼ一定 であるが，長さはレーザ照射出力を変化させることで制御できる.

Abstract: We describe filamentary crack-free modification in silica glass, pyrex glass and soda-lime glass by a CW Laser Backside Irradiation (CW-LBI) method. In this method, an absorbent, which is attached on one side of a glass plate, is irradiated from the opposite side through the glass with $\mathrm{CW}$ laser beam. Ar ion laser is used and metal foil is chosen as absorbent. An intense flash moving from the absorbent toward the opposite direction of the incident laser beam at the speed of approximately $20 \mathrm{~cm} / \mathrm{s}$ is observed and then modification appears in the flashed zone. With increasing irradiated laser power, the length of modification increases but the diameter is almost constant. Our experiments indicate the start of this modification may be due to thermal absorption from the heated absorbent by laser irradiation.

Key words: CW Laser Backside Irradiation, modification, glass, filamentation, laser-induced breakdown

*原稿受付 平成 17 年 12 月 2 日

**学生会員 東京工業大学大学院 *** 東京工業大学工学部（現，ファナック(株)）

†正会員 東京工業大学大学院

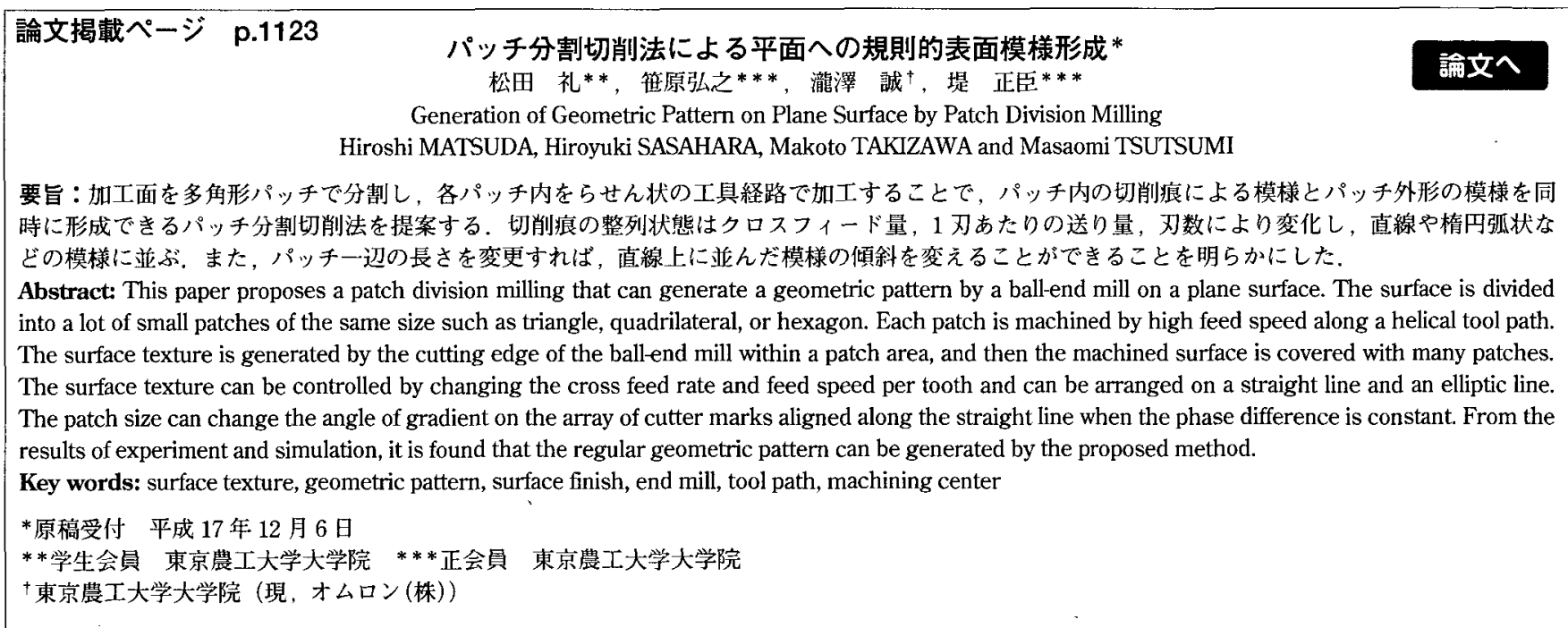

論文掲載ページ p.1128

cBN ビトリファイドホイールの研削性能に及ぼす組織均一化の影響*

一クラスタ研削試験に基づく砥粒切れ刃の挙動解析一

市田良夫**, 梶野 仁***, 佐藤隆之介**, 森本喜隆 ${ }^{* *}$, 佐藤政和

Effects of Uniformity in Structure on Grinding Performance of Vitrified cBN Wheels

- Analysis of Cutting Edge Behavior Based on Cluster Overcut Fly Grinding Test -

Yoshio ICHIDA, Hitoshi KAJINO, Ryunosuke SATO, Yoshitaka MORIMOTO and Masakazu SATO

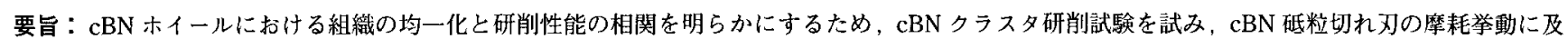
ぼす組織均一化の影響について検討した。ホイール組織の均一化は，作用面上で局部的に発生する砥粒切れ刃犯破碎や脱落を抑制し，切れ刃摩耗の 低滅とそのばらつきを減少させる。

Abstract: This paper deals with the influence of uniformity in structure on the grinding performance of vitrified cBN wheels. In this report, in order to clarify the effect of the uniformity in structure on the behavior of cutting edges during grinding, cluster overcut fly grinding tests are conducted with two types of cBN cluster wheel made by a conventional manufacturing method and by the newly developed manufacturing method referred to as "coating method". The former is denoted by "conventional cluster wheel", while the latter is denoted by "uniform cluster wheel" because it has more uniform structure than that of the conventional cluster wheel. The average radial grain cutting edge wear in grinding with the uniform cluster wheel is smaller than that in using conventional cluster wheel. Moreover, the variation in the radial wear of individual grain cutting edge when using uniform cluster wheel is smaller than that in using conventional cluster wheel, because the fracture and/or releasing of cBN grains that take place locally on the wheel working surface are suppressed by making the wheel structure uniform.

Key words: vitrified $\mathrm{cBN}$ wheel, structure, uniformity, grinding performance, cluster overcut fly grinding test, grain cutting edge wear

*原稿受付 平成 18 年 1 月 12 日

**正会員 宇都宮大学工学部 $* * *$ 正会員 三井金属鉱業(株)

†正会員三井研削砥石(株) 
論文掲載ページ p.1134

超音波振動を援用した金型の鏡面仕上げ加工（第 1 報）* 一ダイヤモンド電着工具を用いた金型鋼の正面研削一

原 圭祐**, 磯部浩已 ${ }^{* * *}$, 吉原英雄 ${ }^{\dagger}$, 久曾神 煌 $^{\dagger \dagger}$, 柳 和久 ${ }^{\dagger}{ }^{\dagger}$

Ultrasonically Assisted Machining for Mirror Finishing of Die (1st Report)

- Face Grinding of Die Steel Using Electroplated Diamond Tool -

Keisuke HARA, Hiromi ISOBE, Hideo YOSHIHARA, Akira KYUSOJIN and Kazuhisa YANAGI

要旨：プラスチック射出成型金型の仕上げとして手作業の研摩が行われている。この研摩工程は，仕上げに数日かかり，機械加工面に比べて幾何精度 が多る。本研究では，ダイヤモンド電着工具を使った超音波振動援用正面研削を試みた，その結果，0.4〜0.8 $\mu \mathrm{mRz}$ の鏡面加工を実現，金型表面を 高速·高精度で仕上げる可能性を見出した。

Abstract: Dies for injection molding parts such as cellular phones and light conductive parts require a high quality surface finish in terms of both appearance and integrity. In order to finish dies, manual polishing by a skilled worker has required after machining processes; such as EDM and milling. But the manual polishing causes poor flatness of dies and time consuming then expensive. So it is desired to establish a machining process to finish dies without manual polishing. In this study, a 3D positioning machine equipped with an ultrasonic spindle was used for grinding experiments. Electroplated diamond tools were equipped. Generally, diamond tool cannot grind steel because of the terrible wear due to chemical reaction between diamond and steel. However, ultrasonically assisted grinding can make fine surface $(0.4 \sim 0.84 \mu \mathrm{mRz})$ of die steel, without observable tool wear. Effects of tool feed rate, radial depth of cut and axial depth of cut were investigated.

Key words: ultrasonically assisted grinding, electroplated diamond tool, die steel, mirror finishing

*原稿受付 平成 17 年 11 月 25 日

**学生会員 長岡技術科学大学大学院 $* * *$ 正会員 長岡技術科学大学工学部 (現，長野工業高等専門学校)

†正会員 (財)にいがた産業創生機桪 ††正会員 長岡技術科学大学工学部

論文掲載ページ p.1139

\title{
棈円振動切削による金型鋼の自由曲面加工（第 1 報）* 一新しい加工方法の提案と高精度 4 軸加工機の開発一 社本英二**, 鈴木教和 ${ }^{*}$, 土屋英滋***, 堀 康德 ${ }^{\dagger}$, 䈷垣 浩 ${ }^{\dagger}$, 吉野 清 $^{\dagger}$
}

Sculptured Surface Machining of Die Steel by Applying Elliptical Vibration Cutting (1st Report)

- Proposal of a New Machining Method and Development of 4-Axis Controlled Precision Machine Tool -

Eiji SHAMOTO, Norikazu SUZUKI, Eiji TSUCHIYA, Yasunori HORI, Hiroshi INAGAKI and Kiyoshi YOSHINO

要旨：焼入れ鋼の 3 次元自由曲面の加工に対して棈円振動切削を適用し，高精度な鏡面加工を実現する新しい金型加工法を提案した。ささらに，これを 実現する同時 4 軸制御の高精度加工機と CAM のポストプロセッサを開発した。開発したシステムを用いてアルミニウム合金の加工を行い，鏡面訨上 げを実現できることを確認した

Abstract: New machining method and system are developed in the present research to realize sculptured surface machining of die steel by applying "elliptical vibration cutting". The present report presents the new machining method, and a 4-axis controlled precision machine tool and special CAM software for the proposed method. It is expected that shape accuracy, tool life, machining efficiency and energy consumption are all improved by the proposed method as compared with the conventional ball end milling. The prototype machine tool is developed by employing an air spindle driven directly by a coreless servo mortar, precision ball screws and precision linear roller guides. The CAM software is developed by utilizing a commercial main processor and developing a new post processor to generate tool paths for the 4-axis controlled motion. A new 3-DOF elliptical vibration system, which is required to complete the present technology, and application to hard materials will be presented in the next reports. It is confirmed in the present report that mirror surface machining of aluminum alloy can be realized by applying the proposed machining method and the developed machine tool and CAM software.

Key words: cutting, elliptical vibration, sculptured surface, 4-axis controlled machine tool, die machining

*原稿受付 平成 18 年 2 月 3 日

**正会員 名古屋大学大学院 $* * *$ 学生会員 名古屋大学大学院

$\dagger($ 株)オークマ

\section{論文掲載ページ $\quad$ p.1146} 超精密直径測定機の開発*

\author{
萩原誠一 $* *$ ，真分幸雄 $* * *$, 境 久嘉 $* *$ ，茂呂澤孝浩 $* * *$ ，山本英樹***，神永哲也 $* * *$ \\ Development of a New Sphere Diameter Measuring Machine \\ Seiichi HAGIWARA, Yukio MAWAKE, Hisayoshi SAKAI, Takahiro MOROSAWA, \\ Hideki YAMAMOTO and Tetsuya KAMINAGA
}

要旨:三次元測定機のプロービングおける偏差補正に用いる校正球の直径測定不確かさの低減を背景とし，独自に超精密直径測定機を開発した。本機は 可変長真空光路の構筑により真空中のレーザ波長を長さ基準とし,アッべの原理の蕨守, 徹底した熱源の排除および優れた測定力安定性を特長として いる。 その結果,再現性が $10.4 \mathrm{~nm}(\sigma)$ ，球の直径測定の不確かさが $74 \mathrm{~nm}(\mathrm{k}=2)$ という結果を得た。

Abstract: A new laser interferometric measuring machine for the sphere diameter has been developed. In the measuring machine, a $633 \mathrm{~nm}$ commercial stabilized He-Ne laser and a variable length vacuum cell made of metal bellows are employed. It became possible to make a vacuum on the laser beam path, so the air turbulences are excluded and the effect of refractive index of the air is eliminated. The Abbe's principle on the alignment of the workpiece with the measurement laser beam is satisfied. Moreover, a control mechanism for measurement contact force, which is coincided with the axis of the measurement laser beam, is developed and applied to the measuring machine. As a result concerning the measuring machine, $10.4 \mathrm{~nm}(\sigma)$ of the measurement reproducibility is confirmed and $74 \mathrm{~nm}(\mathrm{k}=2)$ of expanded uncertainty is estimated.

Key words: sphere diameter measuring machine, laser interferometer, variable length vacuum cell, measurement uncertainty

*原稿受付 平成 17 年 12 月 21 日

**正会員 (株) ミットヨ ***(株)ミットヨ 
Three-Dimensional Measurement of Surface Profile by Focus Method Using Varifocal Lens

Yasuhiro MIZUTANI, Ryoichi KUWANO, Yukitoshi OTANI, Norihiro UMEDA and Toru YOSHIZAWA

要旨：本研究では新たに開発した液圧駆動による可変焦点レンズを用いて計測範囲の拡大をはかった 1 軸の非接触三次元形状計測を提案する.ここで は，可変焦点レンズを用いてオプティカルセクショニングを行う．さらに，液晶格子の格子ピッチを制御魚することにより光軸方向のコントラスト分 布を最適化することで距離検出が可能となる.

Abstract: The purpose of this study is to measure no-contact three-dimensional surface profile by a focus method. A liquid varifocal lens is utilized to change a focal length by liquid pressure. Contrast images along the focal length are obtained by 4-step phase shifting technique using a liquid crystal grating. A distance can be determined by the relation between the pressure of varifocal lens and the peak position of contrast by the Gaussian fitting . An accuracy check of this measurement is conducted by moving a motor stage. The experiment values are in good agreement with calibrated values in the measurement range from 0 to $60 \mathrm{~mm}$ with $\pm 0.3 \mathrm{~mm}$ of accuracy. Surface profiles of a screw and a deep hole with $40 \mathrm{~mm}$ have been measured to demonstrate for this method.

Key words: surface profile measurement, varifocal lens, focus method, liquid crystal grating

*原稿受付 平成 17 年 9 月 7 日

$* *$ 正会員 東京農工大学大学院工学府 $* * *$ 正会員 東京農工大学共生科学技術研究院

†正会員 埼玉医科大学保健医療学部

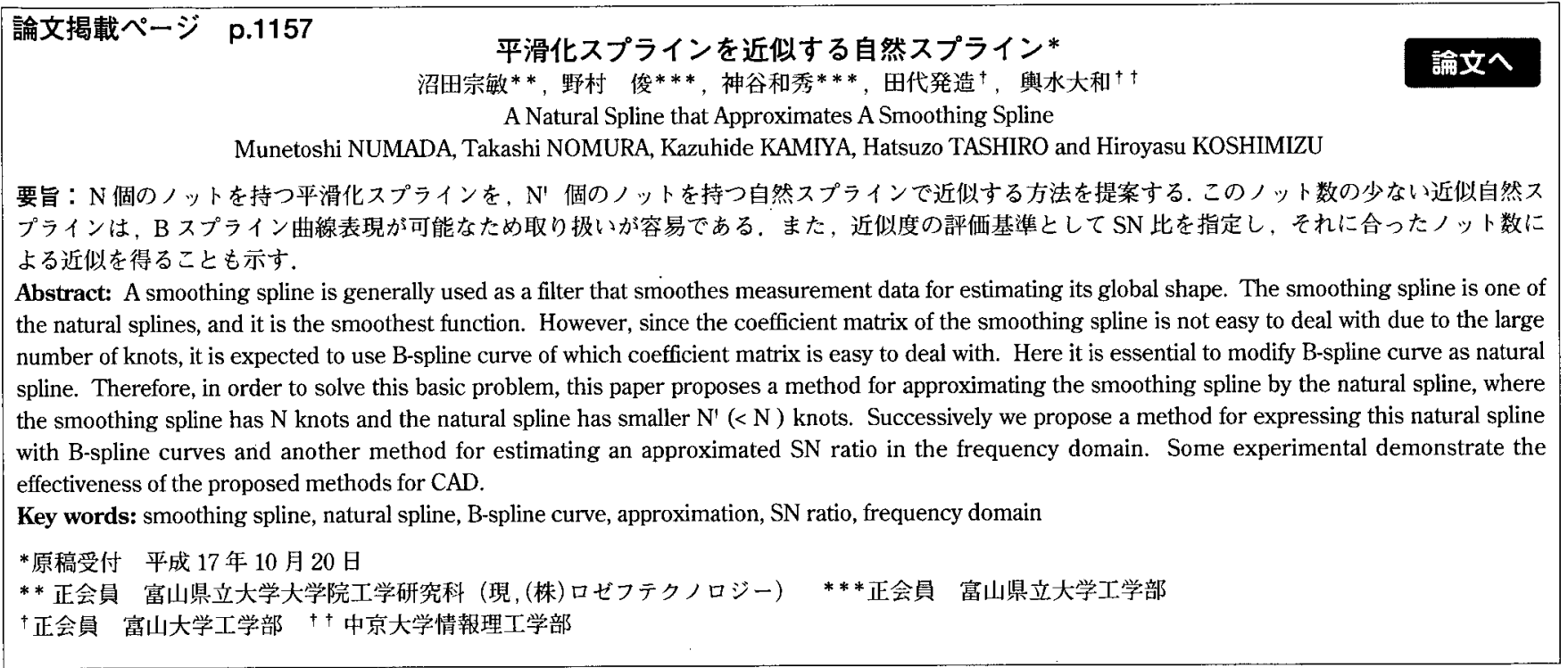

\begin{tabular}{|c|c|}
\hline 論文揭載ページ p.1163 & $\begin{array}{c}\text { マイクロスピンドル用光学式回転精度測定装置の開発* } \\
\text { 一測定基準として球を用いる場合の光学系の基本特性に関する考察— } \\
\text { 藤巻研吾**, 三井公之*** } \\
\text { Development of an Optical Measuring Device for Rotation Accuracy of Micro-Spindle } \\
\text { - Consideration for Basic Characteristics of an Optical System Using a Reference Sphere - } \\
\text { Kengo FUJIMAKI and Kimiyuki MITSUI }\end{array}$ \\
\hline $\begin{array}{l}\text { 要旨 : 従来の測定方法では困難て } \\
\text { る光学式の回転精度測定法の提案 } \\
\text { Abstract: One of the authors has } \\
\text { reflected light from a concave mirr } \\
\text { spindle axis. Therefore we have n } \\
\text { Because a small reference sphere } \\
\text { spindles. This paper refers to the } \\
\text { and then the experimental results } \\
\text { Key words: micro-spindle, rotation }\end{array}$ & $\begin{array}{l}\text { であった小型工作機械用の高速マイクロスピンドルの回転精度評価を行うため，小徍の反射球を測定基準として用い } \\
\text { 案を行った. 本稿では，その測定原埋抢よび光学系の基本特性につけて述べ，製作した装置による実験結果を示す. } \\
\text { s developed an optical measuring device for rotation accuracy of machine tool spindles, which can sense the movement of } \\
\text { rror attached to the spindle end. However it is difficult to obtain small and accurate concave mirrors and to set them to the } \\
\text { newly proposed a measurement method for spindle rotation accuracy using a small steel ball or ball lens as a reference. } \\
\text { re can be used, the proposed measurement system is also appropriate for the evaluation of a high speed miniaturized } \\
\text { principle of the measuring method and the consideration for basic characteristics of an optical system with simulations, } \\
\text { demonstrate the validity of the measurement method. } \\
\text { on accuracy, run-out, optical measurement method, quadrant photo diode }\end{array}$ \\
\hline $\begin{array}{l}* \text { 原稿受付 平成 } 17 \text { 年 } 12 \text { 月 } 2 \text { 日 } \\
*^{*} \text { 学生会貝 慶應義塾大学大学 }\end{array}$ & 院 $* * *$ 正会員 慶應義塾大学 \\
\hline
\end{tabular}




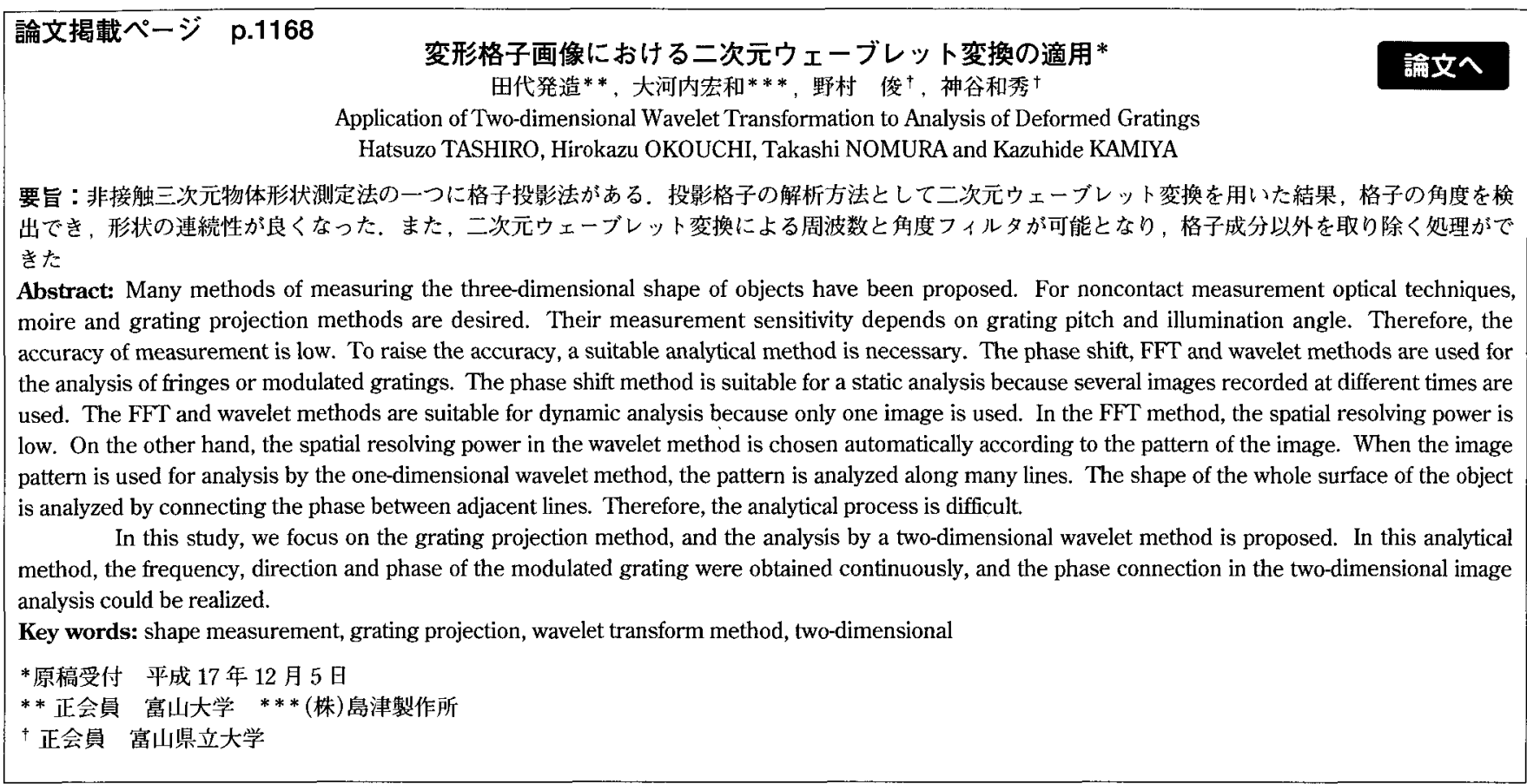

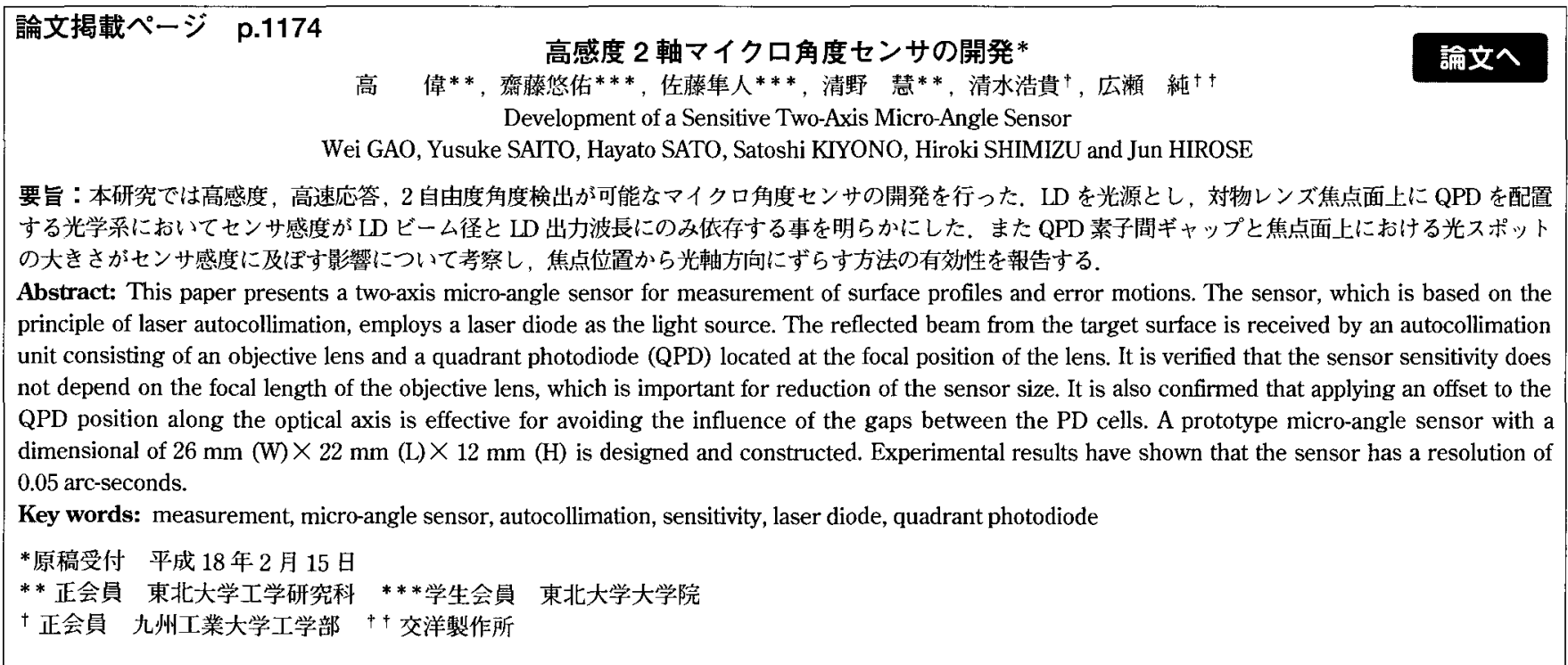

\begin{tabular}{|c|c|c|}
\hline 論文掲載ページ p.1179 & $\begin{array}{c}\text { アクティブ除振装置に対するフィードフォワード制御の一改良* } \\
\text { 涌井伸二** }, \text { 鈴木元気*** } \\
\text { An Improvement of Feedforward Control for Active Anti-Vibration Apparatus } \\
\text { Shinji WAKUI and Genki SUZUKI }\end{array}$ & 寄書へ \\
\hline \multicolumn{3}{|c|}{ Key words: active anti-vibration apparatus, block decoupling, feedforward, pseudo-differential } \\
\hline $\begin{array}{ll}* \text { 原稿受付 } & \text { 平成 } 18 \text { 年 } 3 \text { 月 } 31 \text { 日 } \\
* * \text { 正会員 東京農工大学大学院 }\end{array}$ & *** 関電工 (元，東京農工大学) & \\
\hline
\end{tabular}

